\title{
Isolation of Bacteria in Clarifier Effluent of Sour Pork Industry Able to Produce 1,3-Propanediol from Crude Glycerol
}

\author{
Porntippa Pinyaphong ${ }^{1, a^{*}}$, Pensiri Sriburee ${ }^{2, b}$ \\ ${ }^{1}$ Division of Chemistry, Faculty of Science and Technology, Uttaradit Rajabhat University, \\ Uttaradit 53000, Thailand \\ ${ }^{2}$ Department of Chemistry, Faculty of Science, Chiang Mai University, Chiang Mai 50200, Thailand \\ $a^{*}$ porntippapinyaphong@yahoo.com, bensiri.s@cmu.ac.th
}

Keywords: 1,3-propanediol, crude glycerol, bacteria

\begin{abstract}
The objective of this research was to isolate bacteria that were capable of utilizing glycerol as carbon source and study the optimal condition of 1,3-propanediol production from crude glycerol. The bacteria isolates B-2, B-4 and B-7 was grow and produce 1,3-propanediol in basal medium formula 1,2 and 3 that containing glycerol as a sole carbon sources. The bacteria B-2 produced highest 1,3-propanediol in basal medium formula 2. In addition, the various factors that influenced to crude glycerol fermentation in basal medium formula 2 by the bacteria B-2 were investigated. It was found that the optimal conditions of 1,3-propanediol production were $10 \%$ bacterial inoculums and crude glycerol about $50 \mathrm{~g} / \mathrm{L}$ were added. $\mathrm{pH}$ of basal medium was adjusted around 7 and the bacterial culture was incubated at $30^{\circ} \mathrm{C}$ with shaking at $100 \mathrm{rpm}$ for 3 days. The highest yield of 1,3-propanediol was obtained about $0.4167 \mathrm{~g} / \mathrm{L}$.
\end{abstract}

\section{Introduction}

Crude glycerol about $5-10 \%$ is produced from transesterification of oil for biodiesel production [1]. The global biodiesel production was over 15 billion litres in 2009 and it is still increasing. The forecast for the worldwide production is over 45 billion litres in 2020 [2]. The increased biodiesel production has a created a surplus of crude glycerol, resulting in lower glycerol price. Furthermore, crude glycerol could be considered as a hazardous waste because of its low flash point [3]. The conversion of crude glycerol to higher-value products could be a way to decrease the cost of biodiesel production and to avoid accumulation of crude glycerol. Among potential products from glycerol, 1,3-propanediol (1,3-PDO) has been of increasing interest for many industry. The main application of 1,3-PDO was used as a substrate in polymerization of a new type of polyester, polytrimethylene terephthalate (PTT), which is a type of polyester used in engineering of thermoplastics and in the production of carpets, textile and fibers industries [4]. Moreover, it has been in the production of foods, lubricants and medicines [5]. It also used to improve the properties of solvents, adhesives, laminates, resins, detergents and cosmetics [4]. Over 105 tons of 1,3-PDO are produced annually, primarily through chemical synthesis [6]. However, production of 1,3-PDO from glycerol using chemical method has several disadvantages such as low selectivity, requirement of high pressure and temperature, the use of toxic organic solvents, low yields $(5-15 \% \mathrm{w} / \mathrm{w})$, production of toxic intermediates [7], and the consequently high price hinders the utilization of 1,3-PDO in polymer industries. Therefore, there is much interest in developing an improved and more environmentally favorable process for 1,3-PDO production. One potential method for improved 1,3-PDO production is via the microbial fermentation of glycerol [8]. The use of natural organisms to produce 1,3-propanediol is well studied in bacteria. The common mechanism of glycerol fermentation involves a reductive pathway and an oxidative pathway [4]. In the reductive pathway, a vitamin $\mathrm{B}_{12}$-dependent glycerol dehydratase catalyzes the conversion of glycerol to 3-hydroxypropionaldehyde, and this compound is further reduced to 1,3-PDO by 1,3-propanediol oxidoreductase. In the oxidative pathway, glycerol is dehydrogenated to dihydroxyacetone by a $\mathrm{NAD}^{+}$-linked glycerol dehydrogenase, which is then converted to dihydroxyacetone phosphate by an ATP-dependent dihydroxyacetone kinase. Dihydroxyacetone phosphate is an intermediate of the glycolysis that can be further converted to acetate and to other products, depending on the type of 
bacterium [9]. The natural producers of 1,3-PDO from glycerol are of genera Klebsiella, Clostridium, Citrobacter, Enterobacter and Lactobacilli [10,11,12,13,14,15]. Among these organisms, C. butyricum and $K$. pneumonia, have been reported as the best natural producers because of their substrate tolerance, facultative anaerobes, yield and productivity [16,17]. Unfortunately, a major problem is that the best 1,3-propanediol producers are pathogenic [17] and completely anaerobic conditions through the process of fermentation is operated [18]. Therefore, this research aims to find new bacterial strains from clarifier effluent of sour pork that was able to produce 1,3-PDO in micro-aerobic conditions.

\section{Material and Methods}

First, the wastewater was collected from clarifier effluent of sour pork in Uttaradit Province (Thailand). Sample $(1 \mathrm{ml})$ of waste water was added to $90 \mathrm{ml}$ of PB solution and then 10-fold serially diluted was performed. Each serial dilution was spread onto R2A agar media. Cultures were incubated at $35^{\circ} \mathrm{C}$ for $48 \mathrm{hr}$. Colonies that grown under R2A agar were subcultured for pure culture isolation onto yeast extract mineral medium agar containing $20 \%$ glycerol. Subcultures were incubated for 3 days at $30^{\circ} \mathrm{C}$. After that, the pre-culture was prepared by a full loop of bacterial cell code B-2, B-4 and B-7 were inoculated into a $100 \mathrm{~mL}$ liquid medium which consisted of $10 \mathrm{~g} / \mathrm{L}$ peptone, $10 \mathrm{~g} / \mathrm{L}$ yeast extract, $5 \mathrm{~g} / \mathrm{L}$ beef extract, $5 \mathrm{~g} / \mathrm{L}$ ammonium sulfate and $2 \mathrm{~g} / \mathrm{L}$ glycerol and then were cultivated at $30^{\circ} \mathrm{C}$ in shaker bath at $200 \mathrm{rpm}$ for 3 days. Then, $10 \%$ pre-culture were inoculated into three formula of production medium. $1^{\text {st }}$ formula medium consisted of (per liter)

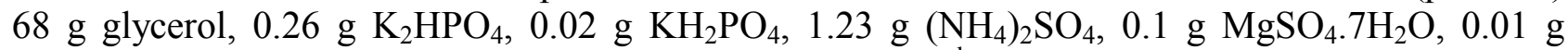
$\mathrm{CaCl}_{2} .2 \mathrm{H}_{2} \mathrm{O}, 0.01 \mathrm{~g} \mathrm{FeCl}_{2} .7 \mathrm{H}_{2} \mathrm{O}$ and $2.0 \mathrm{~g}$ yeast extract. $2^{\text {nd }}$ formula medium contained (per liter) $80 \mathrm{~g}$ glycerol, $3.4 \mathrm{~g} \mathrm{~K}_{2} \mathrm{HPO}_{4}, 1.3 \mathrm{~g} \mathrm{KH}_{2} \mathrm{PO}_{4}, 2.0 \mathrm{~g}\left(\mathrm{NH}_{4}\right)_{2} \mathrm{SO}_{4}, 0.2 \mathrm{~g} \mathrm{MgSO}_{4} .7 \mathrm{H}_{2} \mathrm{O}, 0.02 \mathrm{~g}$ $\mathrm{CaCl}_{2} .2 \mathrm{H}_{2} \mathrm{O}, 0.005 \mathrm{~g} \mathrm{FeSO}_{4} .7 \mathrm{H}_{2} \mathrm{O}$ and $2.0 \mathrm{ml}$ trace element. $3^{\text {rd }}$ formula medium composed of (per liter) $100 \mathrm{~g}$ glycerol, $0.69 \mathrm{~g} \mathrm{~K}_{2} \mathrm{HPO}_{4}, 0.25 \mathrm{~g} \mathrm{KH}_{2} \mathrm{PO}_{4}, 6.0 \mathrm{~g}\left(\mathrm{NH}_{4}\right)_{2} \mathrm{SO}_{4}, 0.2 \mathrm{~g} \mathrm{MgSO}_{4} .7 \mathrm{H}_{2} \mathrm{O}$ and $1.0 \mathrm{ml}$ trace element. The composition of the trace elements (per liter) was $0.07 \mathrm{~g} \mathrm{ZnCl}_{2}, 0.1 \mathrm{~g}$ $\mathrm{MnCl}_{2} .4 \mathrm{H}_{2} \mathrm{O}, 0.06 \mathrm{~g} \mathrm{H}_{3} \mathrm{BO}_{3}, 0.2 \mathrm{~g} \mathrm{CoCl}_{2} .6 \mathrm{H}_{2} \mathrm{O}, 0.02$ g $\mathrm{CuCl}_{2} .2 \mathrm{H}_{2} \mathrm{O}, 0.025 \mathrm{~g} \mathrm{NiCl}_{2} .6 \mathrm{H}_{2} \mathrm{O}$ and $0.035 \mathrm{~g} \mathrm{Na}_{2} \mathrm{MoO}_{4} \cdot 2 \mathrm{H}_{2} \mathrm{O}$. The culture medium was incubated at $30^{\circ} \mathrm{C}$ in an orbital shaker at $100 \mathrm{rpm}$ for $72 \mathrm{hr}$. Samples were taken from the flask cultures every $6 \mathrm{hr}$ for analysis of cell dry weight and 1,3-PDO. All experimental trials were performed in triplicate.

Second, production of 1,3-propanediol from crude glycerol was investigated. A full loop of bacterial cell code B-2 was inoculated into $100 \mathrm{ml}$ pre-culture medium. The culture was incubated in an orbital shaker $(200 \mathrm{rpm})$ at $30^{\circ} \mathrm{C}$ for $60 \mathrm{hrs}$. After that $10 \%$ pre-culture medium was added into $500 \mathrm{ml} 2^{\text {nd }}$ formula production medium and incubated at $30^{\circ} \mathrm{C}$ in orbital shaker at $100 \mathrm{rpm}$ for $72 \mathrm{hrs}$. The factors that effect on 1,3-PDO synthesis of bacterial cell code B-2were investigated such as bacterial inoculums concentration, crude glycerol concentration, initial $\mathrm{pH}$ and incubation temperature. All experimental trials were carried out in triplicate.

The cell dry weight was determined gravimetrically after collection of $4 \mathrm{~mL}$ culture broth for $20 \mathrm{~min}$ at $4^{\circ} \mathrm{C}$ and $4500 \mathrm{rpm}$, including a washing step with distilled water, and drying of the obtained pellet at $105^{\circ} \mathrm{C}$ until constant weight.

The 1,3-PDO concentration in cultivation supernatant was analyzed by HPLC Agilent 1200 equipped with Aminex HPX-87H $(300 \mathrm{~mm}$ x $7.8 \mathrm{~mm})$ column and a refractive index detector. The column temperature was $65^{\circ} \mathrm{C}, 0.5 \mathrm{M}$ sulfuric acid was used as mobile phase at a flow rate of $0.6 \mathrm{ml} / \mathrm{min}$, and an injection volume was $20 \mu \mathrm{L}$ [18].

\section{Results and Discussion}

Isolation of 1,3-PDO producing bacteria from wastewater. Three strains of bacteria isolated from wastewater that collected from clarifier effluent of sour pork could produce 1,3-PDO. They were coding as B-2, B-4 and B-7, respectively. The colony was circular shape, white, and undulates. Bacteria code B-2 was grown in medium containing pure glycerol and produced maximum concentration of 1,3-PDO (Table 1). Therefore, bacteria B-2 was used in the next experiment. 
Table 1 Bacterial isolates and ability to produce 1,3-PDO from glycerol

\begin{tabular}{|c|c|c|}
\hline Microorganism & Cell dry weight ${ }^{*}(\mathrm{mg} / \mathrm{L})$ & 1,3-PDO concentration ${ }^{*}(\mathrm{mg} / \mathrm{L})$ \\
\hline B-2 & $835.30 \pm 41.76$ & $417.60 \pm 20.88$ \\
\hline B-4 & $532.20 \pm 26.66$ & $266.60 \pm 13.33$ \\
\hline B-7 & $545.40 \pm 27.27$ & $88.90 \pm 0.44$ \\
\hline
\end{tabular}

*Average \pm standard deviation error from triplicate

Production of 1,3-PDO from Crude Glycerol. Crude glycerol that collected from transesterificarion of waste oil catalyzed by $\mathrm{KOH}$ for biodiesel production was partially purified. Some properties of purified glycerol such as $\mathrm{pH}$, glycerol content, ash, water content, density and viscosity were $7.11 \pm 0.35,64.58 \pm 3.22 \%, \quad 1.90 \pm 0.09 \%, 2.80 \pm 0.14 \%, \quad 1.205 \pm 0.06 \mathrm{~g} / \mathrm{cm}^{3}$ and $108.40 \pm 5.42 \mathrm{cSt}$, respectively.

The result of glycerol fermentation by bacteria B-2 was initially investigated. Bacteria B-2 was able to grow in basal medium containing crude glycerol, $80 \mathrm{~g} / \mathrm{L}$, which $10 \%$ bacterial inoculums were added and performed at $30^{\circ} \mathrm{C}$ in shaking incubator at $100 \mathrm{rpm}$ for $72 \mathrm{hrs}$. Cell dry weight and 1,3-PDO content were $751.40 \pm 37.50 \mathrm{mg} / \mathrm{L}$ and $375.70 \pm 18.70 \mathrm{mg} / \mathrm{L}$, respectively. Then, the influence of initial inoculums concentration on growth and production of 1,3-PDO in batch fermentation was examined. The effect of bacterial inoculums concentration was shown in Table 2 . The cell dry weight after bacterial cell growth $(751.41 \pm 37.57 \mathrm{mg} / \mathrm{L})$ and the $1,3-\mathrm{PDO}$ content $(375.70 \pm 18.78 \mathrm{mg} / \mathrm{L})$ were highest at $10 \%$ inoculums. These result indicated that the inoculum at $10 \%$ was suitable volume for fermentation that was similar to crude glycerol fermentation of Klebsiella pneumonia SU6 [19].

Table 2 Effect of bacterial inoculums concentration on cell growth and 1,3-PDO production

\begin{tabular}{ccc}
\hline Inoculum concentration $(\%)$ & Cell dry weight ${ }^{*}(\mathrm{mg} / \mathrm{L})$ & $1,3-\mathrm{PDO}$ concentration ${ }^{*}(\mathrm{mg} / \mathrm{L})$ \\
\hline 5 & $417.38 \pm 20.86$ & $208.69 \pm 10.43$ \\
10 & $751.41 \pm 37.57$ & $375.70 \pm 18.78$ \\
15 & $393.48 \pm 19.67$ & $196.74 \pm 9.83$ \\
20 & $462.74 \pm 23.13$ & $231.37 \pm 11.56$ \\
\hline
\end{tabular}

*Average \pm standard deviation error from triplicate

Glycerol is a carbon and energy source for 1,3-PDO production and its availability has an influence on the product formation [20]. Therefore, the effect of crude glycerol that partially purified on growth and production of 1,3-PDO of bacteria B-2 was investigated. The effect of the crude glycerol concentrations on cell growth and 1,3-PDO production in bath fermentation with $10 \%$ inoculums at $30^{\circ} \mathrm{C}$ and shaking at $100 \mathrm{rpm}$ for three days was shown in Table 3 . The highest cell dry weight of bacterial cell growth $(822.51 \pm 41.12 \mathrm{mg} / \mathrm{L})$ and highest 1,3-PDO concentration $(411.25 \pm 20.56 \mathrm{mg} / \mathrm{L})$ were found at $50 \mathrm{~g} / \mathrm{L}$ crude glycerol. When the concentration of glycerol increased, both of cell dry weight and 1,3-PDO production were decreased. This finding indicated that at high amount of glycerol went to be the lethal 3-hydroxypropionaldehyde accumulation which was toxic to microbial cell [17]. Besides, the high concentration of crude glycerol might contain impurities that could inhibit bacterial growth [19].

Table 3 Effect of crude glycerol concentration on bacterial cell growth and 1,3-PDO production

\begin{tabular}{ccc}
\hline Crude glycerol concentration $(\mathrm{g} / \mathrm{L})$ & Cell dry weight ${ }^{*}(\mathrm{mg} / \mathrm{L})$ & $1,3-\mathrm{PDO}^{*}(\mathrm{mg} / \mathrm{L})$ \\
\hline 50 & $822.51 \pm 41.12$ & $411.25 \pm 20.56$ \\
60 & $789.41 \pm 39.47$ & $394.70 \pm 19.73$ \\
70 & $718.93 \pm 35.94$ & $359.46 \pm 17.97$ \\
80 & $751.40 \pm 37.57$ & $375.70 \pm 18.78$ \\
\hline
\end{tabular}

*Average \pm standard deviation error from triplicate

The $\mathrm{pH}$ is one of the main factors influencing cell growth and 1,3-propanediol production of bacteria since the catalytic activity of the enzyme and the metabolic activity of the microorganisms depend on the extracellular $\mathrm{pH}$ [21]. The effect of initial $\mathrm{pH}$ in the range of 3-9 on cell growth and 
production of 1,3-PDO production were studied using 10\% bacterial inoculums and the optimal glycerol concentration at $50 \mathrm{~g} / \mathrm{L}$. The results were shown in Table 4. At pH 7.0, the cell growth and 1,3-PDO production were the highest about $833.54 \pm 41.67 \mathrm{mg} / \mathrm{L}$ and $416.77 \pm 20.83 \mathrm{mg} / \mathrm{L}$, respectively at $72 \mathrm{hrs}$. This corresponded to continuous glycerol fermentation by Clostridium butyricum [22]. At higher $\mathrm{pH}$ such as 9, cell dry weight and 1,3-PDO production were decreased. These results are consistent with Garg and Jain [23] who reported that alkaline condition favored the formation of other products and decrease in the production of 1,3-PDO.

Table 4 Effect of $\mathrm{pH}$ on bacterial cell growth and 1,3-PDO production

\begin{tabular}{ccc}
\hline $\mathrm{pH}$ & Cell dry weight ${ }^{*}(\mathrm{mg} / \mathrm{L})$ & $1,3-$ PDO $^{*}(\mathrm{mg} / \mathrm{L})$ \\
\hline 3 & $393.48 \pm 19.67$ & $196.74 \pm 9.83$ \\
5 & $478.67 \pm 23.93$ & $239.33 \pm 11.96$ \\
7 & $833.54 \pm 41.67$ & $416.77 \pm 20.83$ \\
9 & $524.03 \pm 26.20$ & $262.01 \pm 13.10$ \\
\hline
\end{tabular}

*Average \pm standard deviation error from triplicate

Since, the temperature that needed for cell growth and 1,3-PDO production were different, the effect of temperature $\left(10,20,30,40\right.$ and $\left.50^{\circ} \mathrm{C}\right)$ was studied. The results were shown in Table 5 . Bacterial cell dry weight increased in the temperature range of $10-30^{\circ} \mathrm{C}$. However, the temperature from $30^{\circ} \mathrm{C}$ to $50^{\circ} \mathrm{C}$ caused the decrease in bacterial growth. The maximum cell dry weight and 1,3-PDO concentration were obtained about $833.54 \pm 41.67 \mathrm{mg} / \mathrm{L}$ and $416.77 \pm 20.83 \mathrm{mg} / \mathrm{L}$, respectively, at $30^{\circ} \mathrm{C}$. This phenomenon can be explained that the high temperature might inactivate the enzyme activity in glycolysis and Krebs' cycles, then decreased the carbon metabolism [24]. Therefore, bacterial cell growth was inhibited at high temperature.

Table 5 Effect of temperature on bacterial cell growth and 1,3-PDO production

\begin{tabular}{ccc}
\hline Temperature $\left({ }^{\circ} \mathrm{C}\right)$ & Cell dry weight ${ }^{*}(\mathrm{mg} / \mathrm{L})$ & $1,3-\mathrm{PDO}^{*}(\mathrm{mg} / \mathrm{L})$ \\
\hline 10 & $393.48 \pm 19.67$ & $196.74 \pm 9.83$ \\
20 & $478.67 \pm 23.93$ & $239.33 \pm 11.96$ \\
30 & $833.54 \pm 41.67$ & $416.77 \pm 20.83$ \\
40 & $524.03 \pm 26.20$ & $262.01 \pm 13.10$ \\
50 & $197.35 \pm 9.86$ & $98.67 \pm 4.93$ \\
\hline
\end{tabular}

*Average \pm standard deviation error from triplicate

\section{Summary}

Bacterial strain was isolated from wastewater that collected from clarifier effluent of sour pork was able to synthesize 1,3-PDO from crude glycerol.

\section{Acknowledgement}

This work was granted by the National Research Council of Thailand through Bureau of The Budget.

\section{References}

[1] S.S. Yazdani, R. Gonzalez, Anaerobic fermentation of glycerol: a path to economic viability for the biofuels industry, Curr Opin Biotechnol. 18 (2007) 213-219.

[2] GlobalData., Global Biodiesel Market Analysis and Forecasts to 2020, (2010).

[3] P.A. Selembo, J.M. Perez, W.A. Lloyd and B.E. Logan, Enchanced hydrogen and 1,3-propanediol production from glycerol by fermentation using mixed cultures, Biotechnol Bioeng. 104 (2009) 1098-1106.

[4] H. Liu, Y. Xu, Z. Zheng, D. Liu, 1,3-Propanediol and its copolymers: research, development and industrialization, Biotechnol J. 5 (2010) 1137-1148. 
[5] H. Huang, C.S. Gong, G.T. Tsao, Production of 1,3-propanediol by Klebsiella pneumonia, Appl Microbiol Biotechnol. 98 (2002) 687-698.

[6] A. Nemeth, B. Kupcsulik, B. Sevella, 1,3-Propanediol oxidoreductase production with Klebsiella pneumoniae DSM 2026, World J. Microbiol.Biotechnol. 19 (2003) 659-663.

[7] C. Raynaud, P. Sarc,abal, I. Meynial-Salles, C. Croux, P. Soucaille, Molecular characterization of the 1,3-propanediol operon of Clostridium butyricum encoding a novel coenzyme B12 independent glycerol dehydratase and a 1,3 propanediol dehydrogenase, Proc. Natl. Acad. Sci. USA. 100 (2003) 5010-5015.

[8] D.C. Cameron, N.E. Altaras, M.L. Hoffman, A.J. Shaw, Metabolic engineering of propanediol pathways, Biotechnol. Prog. 14 (1998) 116-125.

[9] A.H. van Gelder, R. Aydin, M.M. Alves, and A.J.M. Stams, 1,3-Propanediol production from glycerol by a newly isolated Trichococcus strain, Microb Biotechnol. 5 (2012) 573-578.

[10] R. Boenigk, S. Bowien, G. Gottschalk, Fermentation of glycerol to 1,3-propanediol in continuous cultures of Citrobacter freundii, Appl Microbiol Biotechnol. 38 (1993) 453-457.

[11] Y. Mu, H. Teng, D.J. Zhang, W. Wang, Z.L. Xiu, Microbial production of 1,3-propanediol by Klebsiella pneumoniae using crude glycerol from biodiesel preparations, Biotechnol Lett. 28 (2006) 1755-1759.

[12] O. Burkhard, E. Grunwaldt, O. Mahmoud, S. Jennewein, Genome shuffling in Clostridium diolis DSM 15410 for improved 1,3-propanediol production, Appl Envir Microbiol. 75 (2009) 7610-7616.

[13] S.E. Pasteris, A.M. strasser de Saad, Sugar-glycerol co-fermentations by Lactobacillus hilgardii isolated from wine, J Agric Food Chem. 57 (2009) 3853-3858.

[14] M. Gungormusler, C. Gonen, G. Ozdemir, N. Azbar, 1,3-Propanediol production potential of Clostridium saccharobutylicum NRRL B-643, Biotechnol. 27 (2010) 782-788.

[15] A. Chatzifragkou, S. Papanikolaou, D. Dietz, A.I. Doulgeraki, G.J. Nychas, A.F. Zeng, Production of 1,3-propanediol by Clostridium butyricum growing on biodiesel-derived crude glycerol through a nonsterilized fermentation process, Appl Microbiol Biotechnol. 91 (2011) 101-112.

[16] M. Gonzalez-Pajuelo, I. Meynial-Salles, F. Mendes, P. Soucaille, I. Vasconcelos, Microbial conversion of glycerol to 1,3-propanediol: physiological comparison of a natural producer, Clostridium butyricum VPI 3266, and an engineered strain, Clostridium acetobutylicum DGI(pSPD5), Appl. Environ. Microbiol. 72 (2006) 96-101.

[17] R.K. Saxena, A. Pinki, S. Saurabh, I. Jasmine, Microbial production of 1,3-propanediol: recent developments and emerging opportunities, Biotechnol. Adv. 27 (2009) 805-913.

[18] D. Szymanowska-Powalowska, A. Drozdzynska, N. Remszel, Isolation of new strains of bacteria able to synthesize 1,3-propanediol from glycerol, Adv Microbiol. 3 (2013) 171-180.

[19] S. Sattayasamitsathit, P. Methacanon, P. Prasertsan, Enhance 1,3-propanediol production from crude glycerol in batch and fed-batch fermentation with two-phase pH-controlled strategy, Electron J Biotechn. 14 (2011) 1-12.

[20] G.L. Zhang, B.B. Ma, X.L. Xu., C. Li, L. Wang, Fast conversion of glycerol to 1,3-propanediol by a new strain of Klebsiella pneumonia. Biochem Eng J. 37 (2007) 256-260.

[21] S.J. Pirt, Principles of microbe and cell cultivation, Blackwell Scientific, 274p. ISBN 9780470690380.

[22] A. Reimann, H. Biebl, W.D. Deckwer, Production of 1,3-propanediol by Clostridium butyricum in continuous culture with cell recycling, Appl Microbiol Biot. 49 (1998) 359-363.

[23] S.K. Garg, A. Jain, Fermentative production of 2,3-butanediol: A review, Bioresource Technol. 51 (1995) 103-109.

[24] P.W. Hochachka, Action of temperature on branch points in glucose and acetate metabolism, Comp. Biochem. Physiol. 25 (1968) 107-118. 